\title{
Van İli Koyunlarında Dictyocaulus filaria'nın Moleküler Karakterizasyonu
}

\author{
Murat ÖRÜN ${ }^{1 \mathrm{a}}$ Vural DENIZZHAN ${ }^{2 b}$ Ayşe KARAKUŞ ${ }^{2 c^{*}}$ \\ ${ }^{1}$ Van Eğitim Ve Araştırma Hastanesi Van, TÜRKIYY \\ ${ }^{2}$ Van Yüzüncü Yıl Üniversitesi Veteriner Fakültesi Parazitoloji Anabilim Dalı, Van, TÜRKIYE \\ ahttps://orcid.org/0000-0003-4358-1215, ${ }^{b}$ https://orcid.org/0000-0002-0531-9550 \\ ${ }^{c}$ https://orcid.org/0000-0002-7151-8777 \\ *Sorumlu yazar: vetci.sona@hotmail.com
}

ÖZET

Bu çalışmada, Van ili Belediye mezbahasına kesim için getirilen koyunlardan nekropsi muayenesi sonucu elde edilen akciğer kıl kurdu olarak bilinen Dictyocaulus (D.) filaria'nın moleküler karakterizasyonunun belirlenmesi amaçlanmıştır. Bu araştırma Mayıs 2019 ile Mart 2020 tarihleri arasında Van ili Belediye mezbahasında yürütüldü. Kesim sonrası makroskopik olarak 1517 koyun akciğeri muayene edildi. Çalışma materyali pozitif çıkan $140(\% 9.22)$ adet koyun akciğerlerinden elde edilen erişkin akciğer kıl kurtlarından oluşmaktadır. Elde edilen erişkin parazitlerin mikroskopik muayenesi sonucunda 56 (\%3.7) adet koyundan D. filaria'a tespit edildi. Tespit edilen $D$. filaria erișkinleri spin kolon yöntemi kullanılarak DNA izolasyonu, ticari kit (Thermo) ile yapıldı. PCR'da akciğer kıl kurdu olan Dictyocaulus filaria'nın 28S rRNA bölgesine ait primerler (FGCTACAAAATCGCATACGAACG, R-ACTCCTTAGCGGTTACCGA) kullanıldı. Calıșmada materyal olarak kullanılan $D$. filaria türünün genomik DNA'sından 28S rRNA gen bölgesi PCR ile amplifiye edildi. Agaroz jelde, 28S rRNA gen bölgesine özgü 952 bç uzunluğunda amplikonlar tespit edildi. Daha sonra, bir PCR ürününden çift yönlü dizi analizinden elde edilen amplikon dizisi, BLAST ile Genbank'taki referans dizilerle karşılaştırıldı. İzolatdan elde edilen genotip tam veya en yakın benzerlikleri ile karşılaştırılarak MEGA 7 programı ile NeighborJoining yöntemi kullanılarak filogenetik ağaç oluşturuldu. Yapılan bu çalışmada D. filaria'nın 952 bç uzunluğunda dizisi (MW405935) NCBI BLAST'ta bulunan NCBI NO: AM039754.1 dizisi ile kıyaslandığında \%100 benzer olduğu tespit edildi. Sonuç olarak, bu araştırma ile Van ili koyunlarında sıklıkla rastlanılan ve akciğer kılkurdu olarak bilinen $D$. filaria'nın 28S rRNA gen bölgesinin DNA dizileme analizi yapılarak moleküler karakterizasyonu tespit edildi. Bu çalışma ile Van ili koyunlarından elde edilen erişkin D. filaria'nın ilk kez moleküler identifikasyonu yapıldı.

\section{MAKALE B İLGÍS İ}

\section{Arastırma Makalesi}

Geliş : 23.09.2021

Kabul: 27.10.2021

Anahtar kelimeler:

Dictyocaulus filaria, Koyun, Moleküler Karakterizasyon

\section{Molecular Characterization of Dictyocaulus filaria in Sheep from Van Province}

\section{A B S T R A C T}

This study aimed to determine the molecular characterization of Dictyocaulus (D.) filaria, known as lungworm, obtained as a result of necropsy examination from sheep brought to the municipal slaughterhouse of Van province for slaughter. This research was carried out between May 2019 and March 2020 in the Van Province Municipality abattoir. After slaughter, 1517 sheep lungs were examined macroscopically. The study material consisted of adult lungworm obtained from the lungs of $140(9.22 \%)$ positive sheep. As a result of microscopic examination of the adult parasites obtained, D. filaria was detected from 56 (3.7\%) sheep. DNA isolation of detected D. filaria adults using spin column method was performed with commercial kit (Thermo). In PCR, primers belonging to the 28S rRNA region of lungworm Dictyocaulus filaria (F-GCTACAAAATCGCATACGAACG, RACTCCTTAGCGGTTACCGA) were used. In the genomic DNA of D. filaria species used as material in the study, 28S rRNA gene region was amplified by PCR. In the agarose gel, $952 \mathrm{bp}$ length amplicons specific to the $28 \mathrm{~S}$ rRNA gene region were detected. Next, the amplicon sequence obtained from bidirectional sequence analysis from a PCR product was compared with reference sequences in Genbank by BLAST. By comparing the genotype obtained from the isolate with its exact or closest similarities, phylogenetic tree was created using the NeighborJoining method with the MEGA 7 program. In this study, the 952 bp long sequence (MW405935) of $D$. filaria was found to be $100 \%$ similar when compared to the NCBI NO: AM039754.1 sequence found in NCBI BLAST. In conclusion, with this study, the molecular characterization of the 28S rRNA gene region of D. filaria, which is frequently encountered in Van province sheep and known as lungworm, was determined by DNA sequencing analysis. In this study, the molecular identification of adult $D$. filaria obtained from Van province sheep was made for the first time.

\section{ARTICLE INFO}

Research article

Received: 23.09.2021

Accepted: 27.10 .2021

Keywords:

Dictyocaulus filaria, Sheep, Molecular Characterization

To Cite: Örün M, Denizhan V, Karakuş A 2021. Van İli Koyunlarında Dictyocaulus filaria'nın Moleküler Karakterizasyonu. MJAVL Sciences. 11 (2) 158-163 


\section{GİRIș}

Pnömoni dünyanın birçok yerinde olduğu gibi Türkiye'de de koyunlarda yaygın olarak görülen bir hastalıktır. Koyunlarda akciğer kılkurtlarının özellikle Dictyocaulus türlerinin neden olduğu pnömoniler sıklıkla görülebilmekte ve ayrıca yağışların fazla olduğu yıllarda önemli maddi kayıplara neden olmaktadır (Umur ve ark. 2006).

Koyun akciğerlerine, trakea ve bronşlara yerleşen $D$. filaria daha çok meraya ilk kez çıkan genç hayvanlarda, solunum bozukluğu, verim kaybı ve gelişme geriliğine neden olmaktadır. Enfeksiyon genellikle kronik seyretmekle beraber zayıf olan ve yeterince beslenemeyen hayvanlarda ciddi klinik semptomlara yol açmaktadır. Dictyocaulosis'in başka hastalıklarla beraber seyrettiğinde hayvanların ölümüne neden olabileceği de bildirilmektedir (Güralp 1981; Soulsby 1986; Çetindağ 1993; Gargili 1995; Umur ve ark. 2006; Taylor ve ark. 2007).

Türkiye'de koyunlarda akciğer nematodlarının oluşturdukları enfeksiyonları belirlemek amacıyla birçok çalışma yapılmıştır. Türkiye'de D. filaria nekropsi muayenesine göre \%13.57-\%31.7 (Güralp 1952; Dik ve ark. 1993; Değer ve ark. 2000; Bağcı ve Bıyıkoğlu 2003; Yıldız 2006), dışkı muayenesine göre \%5.91-\%32 oranları arasında bildirilmiştir (Doğanay ve ark. 1989; Dik ve ark. 1995; Bağcı ve Bıyıkoğlu 2003; Yıldırım ve İça 2005; Kırcalı Sevimli ve ark. 2006). Dünya'da ise akciğer nekropsi sonuçlarına göre \%39.7 ile \%72 oranları arasında (Alasaad ve ark. 2009; Terefe ve ark. 2013; Kuchboev ve ark. 2012) oranında, dışkı bakısı sonuçlarına göre ise \%17.5 ile \%72.44 oranında enfeksiyon bildirilmiştir (Bogale ve ark. 2012; Denbarga ve ark. 2013; Addis ve ark. 2011; Eyob ve Matios 2013; Terefe ve ark. 2013; Borji ve ark. 2012; Gjoni ve ark. 2013).

Türkiye'de koyunlarda akciğer kılkurdu enfeksiyonlarının tespiti için dışkı bakıları ve nekropsiye dayalı birçok çalışma yapılmış olmasına rağmen moleküler olarak sadece Afyonkarahisar yöresinde koyun akciğer kılkurtları ile ilgili bir çalışma yapılmıştır (Köse ve ark. 2017).

Yapılan bu çalışmada; Van yöresi koyunlarında sıklıkla rastlanılan D. filaria'nın 28S rRNA gen bölgesi DNA dizileme analizi yapılarak moleküler karakterizasyonunun ortaya konulması amaçlanmıştır.

\section{MATERYAL VE METOT}

Bu çalışma materyali Mayıs 2019 ile Mart 2020 tarihleri arasında haftada bir kez düzenli olarak gidilen Van Belediye Mezbahası'nda kesimi yapılan 1517 koyun akciğerlerinin makroskobik muayenesi sonucunda; koyunlardan tespit edilen erişkin akciğer kıl kurtlarından oluşmaktadır. Akciğerler, trakeadan başlayarak bronş ve bronşiollere kadar makas ve bisturi yardımı ile kesildi, enfekte koyunlarda ortalama olarak elde edilen 10-20 adet erişkin akciğer kıl kurdu bir pens yardımı ile toplanıp bir kaba konuldu. Toplanan parazitler PBS ile 5 defa yıkandıktan sonra \% 70 'lik etil alkol içerisinde muhafaza edildi. Parazitler Van Yüzüncü Yıl Üniversitesi Veteriner Fakültesi Parazitoloji Anabilim Dalına getirilerek çalışma yapılana kadar $-20^{\circ} \mathrm{C}$ 'de muhafaza edildi. DNA izolasyonundan önce erişkin parazitler literatür yardımıyla morfolojik özelliklerinden yararlanılarak teşhisleri yapıldı (Maff 1971; Güralp 1981; Thienpont ve ark. 1986; Hendrix 1997). D. filaria olarak tespit edilen erişkin parazitler moleküler teşhis ve karakterizasyon için ayrıldı. D. filaria erişkinlerinden yaklaşık $20 \mathrm{mg}$ olacak şekilde her bir kaba ayrı ayrı konuldu ve PBS ile 5 defa yıkandıktan sonra bistüri yardımı ile iyice ezildi ve daha sonra ezilen parazitler ependorf tüplere aktarıldı. Kit içerisinde bulunan lizis buffer ve $20 \mathrm{mg} / \mu \mathrm{L}$ proteinaz-K'dan $25 \mu \mathrm{L}$ konulup 1 gece bekletildikten sonra Thermo Scientific Gene JET Genomic DNA Purification ticari kiti (Kat no:K0722) ile genomik DNA izole edildi ve kullanılıncaya kadar $-20^{\circ} \mathrm{C}$ 'de saklandı.

\section{Mastermix hazırlanışı}

PCR için $25 \mu \mathrm{l}$ içeren toplam hacimde; 10X PCR buffer $2.5 \mu \mathrm{l}, 25 \mathrm{mM} \mathrm{MgCl}_{2} 2 \mu 1,25 \mathrm{mM}$ dNTP $0.5 \mu \mathrm{l}$, her bir primer

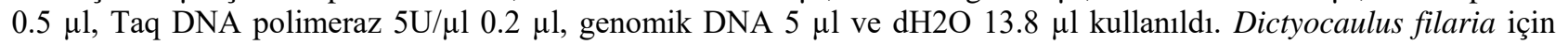
PCR termal döngü şartları ön denaturasyon aşamas $95^{\circ} \mathrm{C}^{\prime} \mathrm{de} 10$ dakika (dk), denaturasyon aşaması $92^{\circ} \mathrm{C}^{\prime} \mathrm{de} 1 \mathrm{dk}$, bağlanma $53^{\circ} \mathrm{C}^{\prime}$ de $1 \mathrm{dk}$ ve uzama $72^{\circ} \mathrm{C}^{\prime}$ da $1 \mathrm{dk}$, döngü sayısı 30 , son uzama aşamas ise $72^{\circ} \mathrm{C}^{\prime} \mathrm{de} 5$ dakika olacak şekilde programlandı (Marka: BİO-RAD, Model: Powerpac Basic). Çalışmada 28S rRNA gen bölgesini çoğaltmak için forward primer: GCTACAAAATCGCATACGAACG ve reverse primer: ACTCCTTAGCGGTTACCGA adl 1 primerler kullanıldı (Köse ve ark. 2017). PCR ürünleri \%2'lik agaroz jelde jel red (Safe view classic, katalog no: G108) ile boyanarak koşturuldu (Elektroforez: BİO-RAD, Model: Powerpac Basic). 100 voltluk elektriksel alanda 1 saatlik koşturma işleminden sonra PCR ürünleri agaroz jel elektroforezinden sonra UV ışık altında kontrol edildi.

\section{Sekans Analizi ve Filogenetik Analiz}

Agaroz jel'de yürütülen ve 952 bç elde edilen PCR ürünlerinden $25 \mu$ PCR tüplerine yerleştirildi ve her numune için 2 $\mu l$ primer (10 pmol) kullanıldı. Tüpler etiketlendi ve sekans analizi için ticari firmaya (Medsantek, İstanbul, Türkiye) gönderildi. Saflaştırılan amplikonlar, Applied Biosystems 377 DNA Sıralayıcı cihazı ile çift yönlü dizi analizi yapıldı. 
Tüm izolatlar için 28S rRNA sekansları MW405935 erişim numarası ile GenBank'a kayıt ettirildi. GenBank'tan alınan AM039754.1, AM039753.1, KX929994.1 kayıt numaralı diziler Clustal W algoritması ile MEGA 7 programında sıralandı. Filogenetik ağaç, Neighbor Joining modeli ve Bootstrap testi (100 tekrar) ile oluşturuldu. İzolatlar arasındaki evrimsel yakınlık Maximum Composite Likelihood ile belirlendi. Elde edilen D. filaria izolatının diziler arasındaki evrimsel yakınlık, MEGA 7 programı ve Neighbor Joining modeli kullanılarak bir UPGMA dendrogramı oluşturuldu (Şekil 2).

\section{BULGULAR VE TARTIŞMA}

Çalışmada mikroskobik muayene ile ilgili literatürler kullanılarak 56 (\%3.7) koyunda $D$. filaria erişkin akciğer k1lkurtları tespit edildi (Maff 1971; Güralp 1981; Thienpont ve ark. 1986; Hendrix 1997). D. filaria parazitlerinden elde edilen PCR amplikonlarından jelde 952 bç ürün boyutu elde edildi (Şekil 1).

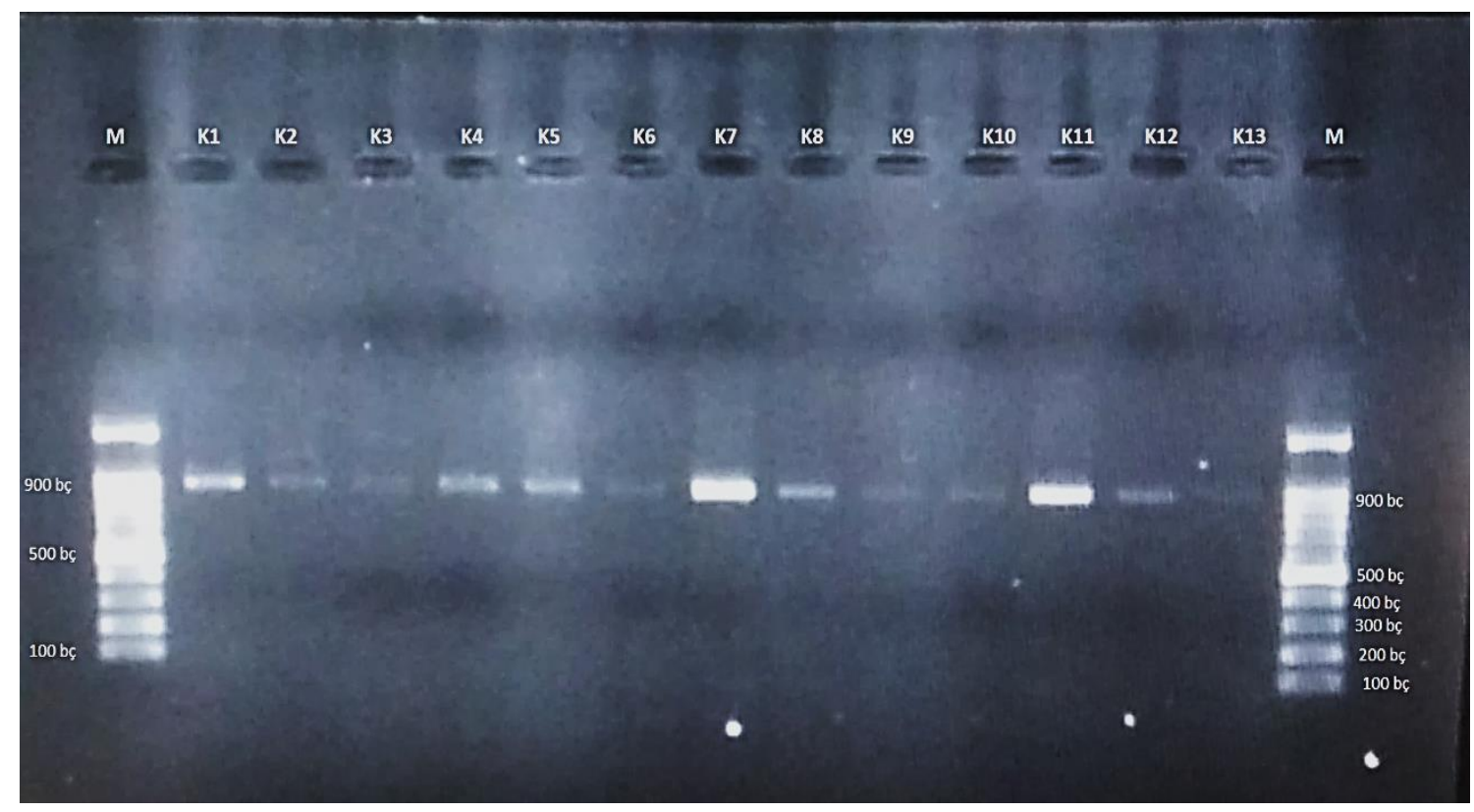

Şekil 1. Koyunlarda bulunan Dictyocaulus filaria'nın 28S rRNA gen bölgesi PZR amplifikasyonu (Amplikon uzunluğu 952 bç). M: Marker, K(1,2,3,4,5,6,7,8,9,10,11,12,13)

\section{Dictyocaulus filaria 28S rRNA geni 952 bç gen dizileri:}

TGTATAGGTACGTGTATGTCACTAACGACTACGCTGACATATTGATAGCACATTCCGTACTGTGATAAAT GAACATGTTGCCCATTATTATTATAATAGTGGTGTCATATGTTTTAACAGTTCGAGTTTGTTGCAAGATGT GATATTAATATTTCAATAGTGCAAAATTTGAATTCGTTTCATTTTTTGCAATGATGTCAGTGTAAACGTTA ATCACCTCTCCGACCCGTCTTGAAACACGGACCGAGGAGTGTAACTTGTACGCGAGTCAATAGGTGTGAT AAACCTAATGGCGCAATGAAAATGAAGACACGTGTAAACGGTTGACATGAGAGATATTTTTCTATATGT GTATATAGCATATAGAAAGTATTGCATCATGGCCCTGTCTAATCTGCATGCAGATGGGCAGAGGTAGAGC GTACAGGTTGCGACCCGAAAGATGGTGAACTATGCCTGAGCAGGATGAAGTCAGAGGAAACTCTGATGG AGGTCCGTATCGGTTCTGACGTGCAAATCGATCGATAGACTTGGGTATAGGGGCGAAAGACTAATCGAA CCATCTAGTAGCTGGTTCCCTCCGAAGTTTCCCCCAGGATAGCTGGAGTTCAAATATAACAATATATACA TATACGGTTATATCCGGTAAAGCGAATGATTAGAGGAATTGGGATCGAAACGATCTCAACCTATTCTCAA ACTTTCAATGGGTATGTTGTCACAGTTTCTTATGGTGTCCTAATGAACTGTTGACATGAACGTGAGCTCCA AGTGGGCCATTTTTGGTAAGCAGAACTGGCGCTGTGGGATGAACCAAACGTTAGGCTAAGGTGCCTAAC TTTTCGCTCATTAGATCCCATAAAAGGCGTTGGTTGATATAGACAGCACGACGGTGGCCATGGAAGTCGT ACGCCCCAAAGGAGATATAAATAACGCAAC

Dictyocaulus filaria'nın amplifiye edilmiş 28S rRNA gen bölgesinin AM039754.1, AM039753.1, KX929994.1 sekansları ile karşılaştırılarak elde edilen fillogenetik ağaç Şekil 2'de gösterildi. Dendogramda Chromadorea sınıfına bağlı $D$. filaria, D. viviparus ve Ostertagia ostertagi türleri arasındaki evrimsel yakınlık $D$. filaria'da \%100 gibi yüksek bir boostrap değeri ile desteklenmektedir. Dış grup olarak Ostertagia ostertagi kullanıldı (KX929994.1). 


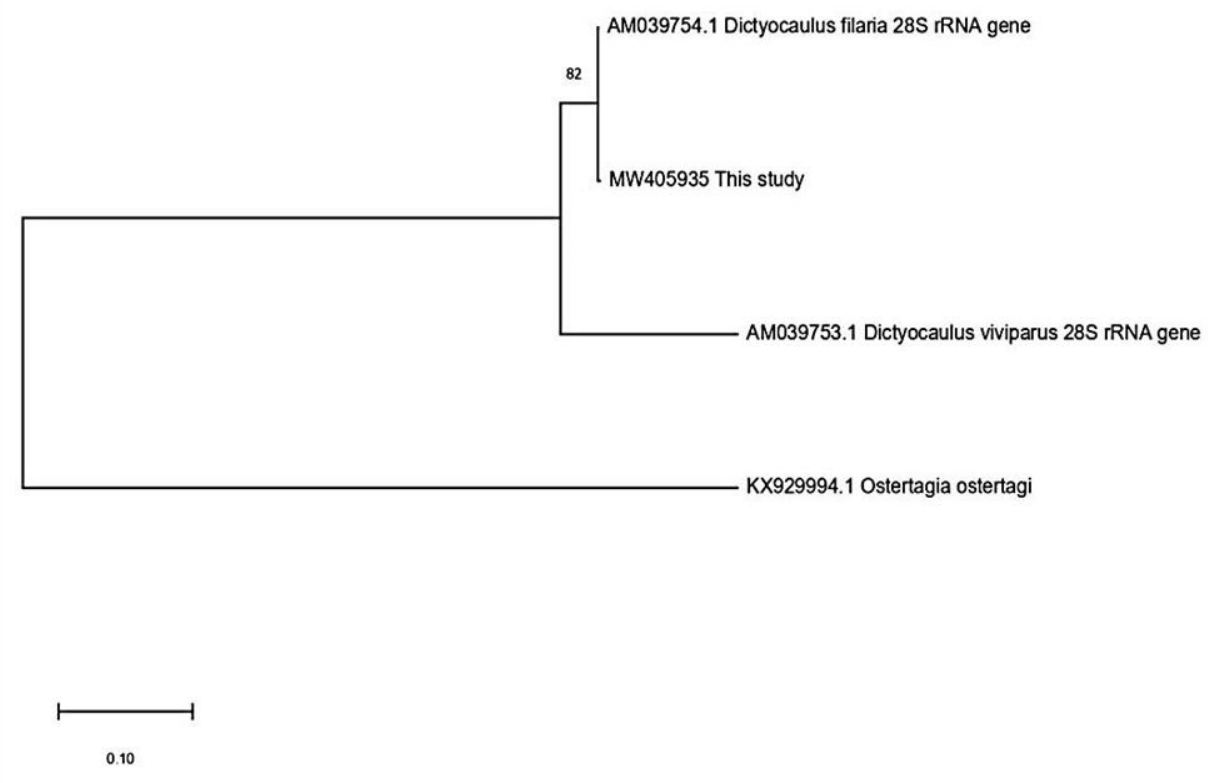

Şekil 2. Bu çalışmada elde edilen izolatlar GenBank'tan elde edilen dizilerle filogenetik ilişkisi (0.10'luk genetik mesafe).

Önemli parazitler arasında yer alan akciğer kılkurtları koyunlarda enfeksiyonlara neden olup, dünyada yaygın bir yayılış göstermektedirler. Türkiye'deki hayvancılık sektöründe önemli sorunlara yol açan bu parazitler, özellikle meraya yeni çıkmış genç hayvanlarda solunum sistemi bozukluklarına, gelişme geriliğine ve verim kayıplarına neden olmaktadır. Ağır enfeksiyonlar, yeterli beslenemeyen ve zayıf hayvanlarda, diğer hastalıklarla da birlikte seyrettiği zaman ölümlere sebebiyet verebilmektedir (Güralp 1981; Soulsby 1986; Celep ve ark. 1990; Çetindağ 1993; Gargili 1995). Dicytyocaulus cinsine ait 3 tür bulunmaktadır. Koyun, keçi ve diğer küçük ruminantlarda $D$. filaria enfeksiyon oluşturmaktadır (Borak 2013).

Türkiye'de koyunlarda görülen akciğer kılkurtları ile ilgili çok sayıda araştırma yapılmıştır. Güralp (1952), Ankara'da nekropsi bakılarına göre koyunlarda D. filaria'nın yaygınlı̆̆ını \%27.83 olarak bildirmiştir. Doğanay ve ark. (1989), Ankara'da yapmış oldukları bir çalışmada koyunların akciğerlerinin \%53.17'sinde invazyon tespit etmiş olup, $D$. filaria oranını $\% 2$ olarak bulmuşlardır. Van ili Bardakçı köyünde $D$. filaria'nın kış aylarında $\% 46.6$ oranıyla en yüksek seviyeye ulaştığı bildirilmiş̧ir (Değer ve Akgül 1991). Konya'da koyunların akciğerlerinde nekropsi bakısına göre $D$. filaria \%13.57 oranında rapor edilmiştir (Dik ve ark. 1993). Konya'da yapılan başka bir çalışmada ise koyun dışkı muayenesinde D. filaria \%36.6 oranında tespit edilmiştir (Dik ve ark. 1995). Gargili (1995), Trakya yöresinde bulunan koyunlarda $D$. filaria'nın yayılışını \% 19.85 olduğu tespit etmişlerdir. Kayseri ilinde yapılan bir çalışmada koyunların \%13.5'inin D. filaria ile enfekte olduğu bildirilmiştir (Yıldırım ve İça 2005). Afyonkarahisar ili koyunlarında bulunan helmint türlerini belirlemek amacıyla yapılan çalışmada kesim sonrası yapılan inceleme sonucunda koyunların akciğerlerinde \%5.91 oranında $D$. filaria tespit edilmiştir (Kırcalı Sevimli ve ark. 2006). Kırıkkale ili koyunlarında akciğer helmintlerin yaygınlığ 1 belirlemek amacıyla yapılan bir çalışmada $D$. filaria'nın \%23.5 oranında tespit edildiği rapor edilmiştir (Yıldız 2006). Bursa ilinde koyunlarda akciğer kılkurtlarının yaygınlığını ortaya koymak amacıyla 104 koyundan alınan dışkı örneğinin incelenmesi sonucu \%45.1'inde akciğer kılkurtları tespit edilmiş olup, bu oran içerisinde D. filaria'ya \%2.9 oranında rastlandığı bildirilmiştir. Ayrıca koyun akciğerlerinin nekroskopik muayenesi sonucu D. filaria ile enfeksiyon oranı \%3.2 olarak bulunmuştur (Girişgin ve ark. 2008). Konya Bozdağ (n:115) ve Ankara Nallıhan'da (n: 27) bulunan Anadolu yaban koyunlarından toplanan 142 dışkı örneğinin \%2.11'inde D. filaria tespit edilmiştir (Emir 2013). Türkiye'nin farklı bölgelerinde yapılan çalışmalarda koyunlarda D. filaria'nın önemli bir akciğer paraziti olduğu bildirilmektedir. Çalışmada elde edilen erişkin parazitlerin mikroskobik muayeneleri sonucunda 56 (\%3.7) adet koyundan $D$. filaria'a tespit edildi. Bu çalışmada elde edilen bulgular yapılan bazı çalışmaları desteklemektedir (Girişgin ve ark. 2008; Kırcalı Sevimli ve ark. 2006; Doğanay ve ark. 1989). Bu çalışma; bazı araştırıcıların (Güralp 1952; Dik ve ark. 1993) çalışmaları ile paralellik göstermemektedir. Bu farklılıkların nedeni olarak hayvanlardaki parazit sayısı, bölgesel veya mevsimsel farklılıkların oluşması; konak ve parazitin özellikleri, konak-parazit arasındaki ilişki ve bölgesel özellikler gibi birçok faktörün ilişkisinden etkilenmektedir. Van ili soğuk ve karasal iklime sahip olmasından dolayı parazitlerin gelişim süreçlerini değiştirebilmekte ayrıca hayvan sahipleri 
tarafından son yıllarda kontrolsüz şekilde antiparaziter ilaçların kullanılması parazit yükünün değişmesine neden olabilmektedir.

Dünya'da dört Dictyocaulus türü arasında (D. viviparus, D. eckerti, D. arnfieldi ve D. filaria) moleküler yöntemler kullanarak 28S rRNA gen bölgesi üzerinde oransal benzerlikler ortaya konmuştur (Epe ve ark. 1997). Dictyocaulus türlerine yönelik dünyada yapılan moleküler çalışmalar mevcut olup; bu çalışmalar $D$. filaria'nın 28S rRNA gen bölgesini kapsamamaktadır. Van yöresi koyunlarında yapılan bu çalışma ile akciğer kılkurdu türü olan $D$. filaria'nın 28S rRNA gen bölgesinin DNA dizileme analizi ile moleküler karakterizasyonu yapılmıştır.

Türkiye' de yapılan çalışmaların birçoğu $D$. filaria'nın yaygınlığını değerlendirmek üzerine yapılmış olup, konuyla ilgili tek moleküler çalışma Afyon'da yürütülmüştür. Afyon'daki çalışmada D. filaria, Cystocaulus ocreatus ve Muellerius capillaris'in 28S rRNA gen bölgesinin moleküler identifikasyonu yapılmıştır (Köse ve ark. 2017). Fakat Afyon'da yapılan çalışmada veriler gen bankta kayıt edilmediğinden dolayı çalışmamızdaki gen dizilimi verileri ile benzerliği karşılaştırılamamıştır.

Sonuç olarak, bu araştırma ile Van ili koyunlarında $D$. filaria'nın 28S rRNA gen bölgesinin DNA dizileme analizi yapılarak moleküler karakterizasyonu ortaya konulmuştur. Çalışmada D. filaria'nın 952 bç uzunluğunda dizisi (MW405935) NCBI BLAST'ta bulunan NCBI NO: AM039754.1 dizisi ile kiyaslandiğında \%100 benzerlik göstermektedir. Elde edilen sonuçların yapılacak olan moleküler epidemiyolojik ve filogenetik çalışmalara ışık tutacağı kanısindayız.

\section{ÇIKAR ÇATIŞMASI}

Yazarlar, bu yazı ile ilgili herhangi bir çıkar çatışması olmadığını beyan ederler.

\section{YAZAR KATKISI}

Tüm yazarlar eşit katkı sağlamıştır.

\section{KAYNAKLAR}

Addis M, Fromsa A, Ebuy Y 2011. Study on the prevalence of lungworm infection in small ruminants in Gondar Town. Vet. Res. 4:85-89.

Alasaad S, Morrondo P, Dacal-Rivas V, Soriguer RC, Granados JE, Serrano E, Zhu XQ, Rossi L, Pérez JM 2009. Bronchopulmonary nematode infection of Capra pyrenaica in the Sierra Nevada masif. Vet. Parasitol. 164:2-4.

Bağcı Ö, Bıyıkoğlu G 2003. İstanbul'da değişik kombinalarda kesilen koyunlarda akciğer kılkurtlarının yayılışı. Türkiye Parazitol. Derg. 27:139-43.

Bogale B, Ebre A, Melaku A 2012. Ovine lungworm infection: Prevalence, species composition and associated risk factors in Dessie Zuria district. Afr. J. Basic. Appl. Sci. 4(3): 73-76.

Borak M 2013. Verminöz pnömonili koyunlarda indüklenebilir nitrik oksit sentaz (inos) protein ekspresyonunun immunhistokimyasal olarak belirlenmesi [Yüksek Lisans Tezi]. Van: Yüzüncü Y1l Üniversitesi.

Borji H, Azizzadeh M, Ebrahimi M, Asadpour M 2012. Study on small ruminant lungworms and associated risk factors in northeastern Iran. Asian. Pac. J. Trop. Med. 853-856.

Celep A, Açıcı M, Çetindağ M, Coşkun ŞZ, Gürsoy S 1990. Samsun yöresi sı̆̆ırlarında helmintolojik araştırmalar. Etlik Vet. Mikrobiyol. Derg. 6:117-30.

Celep A, Açıcı M, Çetindağ M, Gürbüz İ 1995. Samsun yöresi koyunlarında paraziter epidemiyolojik çalışmalar. Türkiye Parazitol Derg. 19:290-6.

Çetindağ M 1993.Samsun yöresi koyunlarında akciğer nematodları. Türkiye Parazitol. Derg. 17:88-92.

Değer S, Akgül Y 1991. Van ili Bardakçı köyünde bulunan endoparazitlerin epidemiyolojisi. Yüzüncü Yı1 Üniv. Vet. Fak. Derg. 2,1-2:11-22.

Değer S, Biçek K, Akdemir C, Taş Z 2000. Van Belediye mezbahasında kesilen koyunlarda akciğer kılkurtlarının yayılışı. Yüzüncü Yıl Üniv. Vet. Fak. Derg. 27:215-36.

Denbarga Y, Mekonnen A, Abebe R, Sheferaw D 2013. Prevalence of lungworm infection in sheep around Bahir-Dar Town. APG. 4 (2):54-58.

Dik B, Sevinç F, Güneği HB 1993. Konya Et ve Balık Kombinası'nda kesilen koyunlarda akciğer kılkurtlarının yayılışı. Türk Vet. Hek. Derg. 5(1):39-42.

Dik B, Sevinç F, Sevinç M 1995. Konya yöresi koyunlarında akciğer kıl kurtlarının yayılışı. Veterinarium. 6(1-2): 7981.

Doğanay A, Burgu A, Toparlak M 1989. Ankara yöresinde koyunlarda Metastrongylose. Etlik Vet. Mikrobiyol. Derg. 6(5): 99-113.

Emir H 2013. Anadolu yaban koyunlarında (Ovis gmelinii anatolica) sindirim sistemi helmintleri. [Doktora Tezi]. Ankara. Ankara Üniversitesi. 
Epe C, Samson-Himmelstjerna GV, Schnieder T 1997. Differences in a ribosomal DNA sequence of lungworm species (Nematoda: Dictyocaulidae) from fallow deer, cattle, sheep and donkeys. Res. Vet. Sci. 62:17-21.

Eyob E, Matios L 2013. The prevalence and risk factors associated with ovine lungworm infestation in the Asella province Central Ethiopia. J. Parasitol. Vector. Biol. 25-30.

Gargili A 1995. Trakya'da kıvırcık koyunlarında akciğer nematodlarının yayılışı. [Doktora Tezi]. İstanbul. İstanbul Üniversitesi.

Girişgin O, Şenlik B, Girişgin AO, Akyol V 2008. Studies on sheep lungworms in Bursa province of Turkey: Determination of prevalence and relationships between larval output and parasite burden in the lungs. Pakistan J. Zool. 40(5):365-9.

Gjoni N, Biba N, Bizhga B, Laçi D, Zalla P, Sherko E, Xhemollari E 2013. The bronchopulmonary strongylats in goats of Elbasan district. Anglisticum Journal. 2(4):353-361.

Güralp N 1952. Anadolu koyunlarında görülen Metastrongylidae nevilerine dair sistematik araştırmalar. Ankara Üniv. Vet. Fak. Yayınları, Ankara.

Güralp N 1981. Helmintoloji. 2. Baskı, Ankara Üniv Vet Fak, Ankara Üniversitesi Basımevi, Ankara. 368: 338-65.

Hendrix CM 1997. Laboratory Procedures for Veterinary Technicians, Third Edition, Pratt PW. ed. USA: VMD Mosby, Inc.

Kırcalı Sevimli F, Kozan E, Köse M, Eser M 2006. Dışkı muayenesine göre Afyonkarahisar ili koyunlarında bulunan helmintlerin yayılışı. Ankara Üniv. Vet. Fak. Derg. 53: 137-40.

Köse M, Erdoğan M, Kartal K 2017. Afyonkarahisar Yöresi Koyun Akciğer Kıl kurdu Türlerinin Moleküler Karakterizasyonu. Atatürk Üniversitesi Vet. Bil. Derg. 2(3): 283-8.

Kuchboev AE, Karimova RR, Ruziev BK, Azimov DA 2012. Ecological aspects of nematodes of the family Protostrongylidae, parasites of bovidae. Sci. Parasitol. 13(1):17-25.

Ministry of Agriculture, Fisheries and Food (MAFF) 1971. Manuel of Veterinary Parasitological Laboratory Techniques, London: HMSO. Technical Bulletin. 18.

Soulsby EJL 1986. Helminths, artropods and protozoa of domesticated animals. 7th Ed.,Bailliere Tindall, London. 263 (8): 271-6.

Taşan E, Köroğlu E, Altaş MG 1997. Elazığ bölgesinde akciğer kılkurtlarının yayılışı. F. Ü. Sağlık Bil. Derg.11: 273-6.

Taylor MA, Coop RL, Wall R 2007. Veterinary Parasitology. Third edition, Blackwell Publishing, UK. 197.

Terefe Y, Tafess K, Fekadie G, Kebede N 2013. Prevalence of lungworm infection in small ruminants in North Gondar zone, Amhara National Regional State, Ethiopia. J. Parasitol. Vector. Biol. 5(4):40-45.

Thienpont D, Rochette F, Vanparijs OFJ 1986. Diagnosis Helminthiasis by Coprological Examination. Second Edition, Janssen Research Foundation, Belgiu.

Umur Ş, Köroğlu E, Güçlü F, Tınar R 2006. Helmintoloji, Nematoda. Ed. Tınar R, Nobel Yayın Dağıtım, Ankara. 965:213-461.

Umur Ş, Özkan MÖ 1998. Kars yöresi sı̆̆ır ve koyunlarında akciğer kılkurtları. Turkiye Parazitol. Derg. 22:88-92.

Yıldırım A, İça A 2005. Kayseri yöresinde koyunlarda akciğer kılkurdu enfeksiyonlarının prevalansı. Erciyes Üniv. Vet. Fak. Derg. 2(2): 73-8.

Yıldız K, Aydenizöz M 2001. Kırıkkale koyunlarında helmintlerin yayılışı. Ankara Üniv. Vet. Fak. Derg. 48: 179-82.

Yıldız, K 2006. Prevalence of lungworm infection in sheep and cattle in the Kirikkale province. Turkiye Parazitol. Derg. 30: 190-193. 